\title{
Numerical Evaluation of the Behavior of Steel Frames with Gypsum Board Infill Walls
}

\author{
Mehrdad Movahednia, S. Mohammad Mirhosseini (D), and Ehsanollah Zeighami \\ Department of Civil Engineering, Arak Branch, Islamic Azad University, Arak, Iran \\ Correspondence should be addressed to S. Mohammad Mirhosseini; m-mirhoseini@iau-arak.ac.ir
}

Received 27 July 2018; Revised 23 December 2018; Accepted 9 January 2019; Published 3 March 2019

Academic Editor: Antonio Formisano

Copyright (c) 2019 Mehrdad Movahednia et al. This is an open access article distributed under the Creative Commons Attribution License, which permits unrestricted use, distribution, and reproduction in any medium, provided the original work is properly cited.

In this paper, the behavior of steel frames with gypsum board infill walls is studied through finite element simulation. For this purpose, a typical steel frame with infill wall which had been previously tested is considered as a benchmark model. The accuracy of a numerical model is verified by calibrating the results of the finite element simulation against those of a corresponding experimental specimen. In the next step, a parametric study is performed on four models in order to study the effects of gypsum board thickness, inclusion of fibers as reinforcement in the infill wall, and local strengthening of the peripheral regions of the infill wall. Each of these factors is related to considerable performance improvement such as strength and ductility of the models. It is observed that adding fibers to the infill wall leads to increase in the strength and ductility of the models up to 3.2 and 6.3 times, respectively. Doubling the thickness of the infill wall results in an increase of 6.7 and 3.3 times in strength and stiffness, respectively; however, this modification causes a significant decrease in the ductility of the infilled frames. Negligible improvement in strength and ductility is achieved through local strengthening of the peripheral regions of the infill walls, whereas it leads to a $30 \%$ increase in the stiffness of the models.

\section{Introduction}

Observations from past earthquakes indicate that, in many cases, infill walls, which have been designed and constructed according to the existing design code requirements, have poor seismic performance during earthquakes even those are of moderate intensity. This unacceptable performance is mainly originated from the fact that the majority of these infill walls is made of masonry material and hence has inherent low ductility. Apart from the low strength and being very heavy which induce considerable seismic demands, infill walls also tend to lose their integrity upon experiencing few cycles from earthquakes. Their stiffness and strength degradation also adds to their weakness. Because there are many buildings with masonry infill walls throughout the world, studying the vulnerability of these structural components is very important. Also, proposing a feasible method to improve the seismic performance of infill walls by introducing new structural systems as a replacement to these walls is considered as a priority. Using new industrialized materials instead of old-fashioned masonry can be regarded as a solution to overcome the weaknesses of traditional infill walls. In this regard, it is necessary to study the physical and mechanical properties of these materials which are superior to masonry.

Gypsum, in the form of panels, roof diaphragms, and board partitions, is finding more and more applications in the building industry. Because of low tensile strength and also brittleness of gypsum, its combination with different types of fibers has been gained attention in several researches. One of the possible uses of these panels is infill walls in frame buildings. Bahreini and et al. [1] evaluated brick infill walls under in-plane and out-of-plane loading. They concluded that the studied infilled frames show significant vulnerability when excited under simultaneous inplane and out-of-plane loads compared to when theses load components are applied to the models independently. One of the most important response characteristics of the infilled 
frames is the fundamental period of these structural systems. This parameter has a direct effect on the seismic demand and hence the severity of the design-level earthquake on the studied structure. Asteris et al. [2, 3] and Asteris et al. [4, 5] investigated the fundamental period of infilled frames under various possible cases. Zak et al. [6] studied the compressive behavior of bricks having fibrous gypsum. A total of 21 different test series were carried out with different composition of earth, cement, gypsum, hemp, and flax fibers. They observed that the compressive strength of bricks was highly dependent on the density of the mixture. The fibers hemp and flax had rather low influence on the compressive strength of bricks, but they have significant effects on the tensile behavior of the bricks. Cement and gypsum as additives, as they seem to reduce the binding force of the clay minerals, lead to a highly decreased strength. Ali and Grimer [7], studied the inclusion of commercially available $E$ glass fibers to reinforce a gypsum plaster matrix and produce a strong composite material. They studied the effect of glass content on the flexural, tensile, compressive, and impact strengths of glass fiber plaster composite. They reported an increase of up to three times and four times in the flexural and tensile strengths of specimens having $10 \%$ of glass fibers compared to those in unfibred specimens. Also, adding of glass fibers led to modification of the fracture mode of gypsum plaster from brittle type to quasi-plastic type.

Wu and Dare [8] studied the flexural and shear behaviors of composite lintels above the door and window openings of glass fiber-reinforced gypsum (GFRG) constructions. These lintels are constructed by filling reinforced concrete into the hollow cores of the GFRG walls which are composed of gypsum plaster and reinforcing glass fibers. They carried out experimental beam testing. The typical failure modes and corresponding ultimate strengths were evaluated, and theoretical design models and guidelines were proposed for these panels.

In recent years, the use of fiber-reinforced gypsum boards as structural members due to their significant strength and ductility over corresponding gypsum boards has been given special attention among researchers. Janardhana et al. [9] performed static cyclic tests on a series of gypsum boards reinforced with glass fibers. They observed that, in all specimens, pinching governed the hysteretic behavior. They also performed a parametric study using calibrated finite element simulation. A series of shaking table tests on a full-scale two-story building were carried out by Macillo et al. [10]. During the higher levels of excitations, it was observed that some of the gypsum boards were crushed at the corners and detached from their interface with a surrounding steel frame. Selvaraj and Madhavan [11] tested a total of 24 full-scale single stud panels on unsheathed and both side sheathed panels. The parameters studied were C channel dimensions, sheathing thickness, and fastener spacing. The experimental results were compared with the design specifications of AISI and found to be conservative. Amer et al. [12] studied ways of providing a better behavior of nonstructural gypsum partition walls and to provide damping methods in order to improve such behavior. Nine full-scale wall specimens were tested under static cyclic loading which include light gauge steel studs and sheathed on both sides with a gypsum board. Three specimens were constructed with single rubber grommet dampers, three specimens with double dampers, and three wall specimens were constructed without a damping system. Macillo et al. [13] tested four shear walls under monotonic and cyclic loads including one wall with all finishing materials. The studied system was a sheathing-braced cold-formed steel (CFS) solution, in which the seismic resistant elements were made of CFS stud shear walls laterally braced with gypsumbased panels. The sheathing panels were attached to a CFS frame by means of ballistic nails, whereas clinching points were used for steel-to-steel connections. The results showed the behavior factor of specimens range between 3.43 and 4.31.

Fiber-reinforced gypsum panels have also been used as structural panels in rapid construction projects. By carrying out extensive experimental and theoretical investigations into the structural behavior of glass fiber-reinforced gypsum (GFRG) walls, Wu [14] also offered a structural design methodology for GFRG walls and an associated building system. The tests included the evaluation of the axial compressive and in-plane flexural strengths on gypsum panels. Mujeeb and Udhayasakthi [15] proposed a possible use of these panels as infill walls but did not investigate the performance of GFRG for this utilization. A similar possible use of these panels was also made by Paul et al. [16]. Cherian et al. [17] made an overview of research and development carried out at IIT Madras, using glass GFRG panels, to provide an innovative solution for rapid and affordable mass housing. $124 \mathrm{~mm}$ thick GFRG panels made from recycled industrial waste gypsum from the fertilizer industry were prefabricated with cellular cavities inside, which can be filled with reinforced concrete if required and can be used as walls as well as floor slabs. Extensive experimental investigations were carried out on the proposed panels as a load-bearing system without beams and columns in multistory buildings up to 8-10 stories. Also, they constructed a two-story fourapartment demonstration building as a pilot project.

In this paper, the behavior of steel frames with gypsum infill walls as a replacement to the traditional masonry infill walls is studied numerically. First, the accuracy of a modeling method is verified against benchmark experimental results. In the next step, a parametric study is performed on four models in order to study the effects of gypsum board thickness, inclusion of fibers as reinforcement in the infill walls, and local strengthening of the peripheral regions of the infill walls.

\section{Materials and Methods}

In this part, the assumptions of the modeling including the element characteristics, mechanical and physical properties of the materials, boundary conditions, and loading and analysis methods are elaborated. It is noteworthy that some of the assumptions of material behavior and modeling procedure in this study follow those employed in the study of Bahreini et al. [1]. They studied the in-plane and out-ofplane interactions of masonry infill walls which were 
different from the main target of this study, i.e., performance of gypsum board panels as infill walls.

In this paper, general-purpose finite element software Abaqus is used for modeling and analysis. The employed method is simplified-micro in which bricks are modeled individually and the properties of mortar are taken into account by zero-length cohesive elements. Besides, to consider the mortar's thickness, half of the mortar thickness is included in the brick's thickness. Because of the highly brittle and nonlinear response of infilled frames and the associated numerical convergence problems, the utilized numerical solving method is the central difference. Therefore, loadings are applied to the models during a quasi-static procedure by controlling the ratio of the kinetic energy to the input energy of the model to be less than $10 \%$ throughout the analysis [1].

First-order, reduced integration hexahedral continuum elements (C3D8R) are used for modeling bricks. Cohesive elements (COH3D8) are considered for modeling mortar. For modeling frame members and gypsum infill walls as well, first-order, reduced integration quadrilateral shell elements (S4R) are utilized. Sensitivity analyses are performed on the models, and the converged mesh size of $2 \mathrm{~cm}$ with two elements alongside the brick thickness is selected [1].

\subsection{Materials Behavior}

2.1.1. Gypsum. In this study, gypsum panels, shown in Figure 1(a), are used as a replacement to traditional masonry infill walls. In order to determine the mechanical properties of the material, several standard tests have previously been performed by Tabeshpoor and Movahednia [18]. An example of a specimen in a standard test for determination of the compressive strength of a panel is shown in Figure 1(b). The average mechanical properties of the gypsum are presented in Table 1.

"Concrete damage plasticity" model is used for modeling gypsum material with the stress-strain behavior proposed by Tabeshpour and Movahednia [18]. They studied the effects of various parameters including the addition of plastic mesh and powder fibers on the behavior of gypsum boards by performing several tensile, compressive, shear, and bending standard tests. The results of their study indicate the significant improvement in the strength and ductility of gypsum, thanks to the addition of the plastic mesh and powder fibers. The assumed stress-strain curve of gypsum is presented in Figure 2.

2.1.2. Mortar. A quadratic stress criterion is used for damage initiation in mortar under shear and tensile behaviors as equation (1) $[20,21]$. Additionally, damage evolution of mortar is considered as an inverse exponential function with the power of 10 and ultimate relative displacement of $1 \mathrm{~mm}$ as equation (2), which is schematically illustrated in Figure 3 [22]. Where $t=$ stress, $t, s$ (index) $=$ tangential directions along surface, $n$ (index) $=$ perpendicular to the surface direction, $\delta_{\mathrm{m}}^{0}=$ effective relative displacement during first failure, $\delta_{\mathrm{m}}^{\mathrm{f}}=$ effective relative

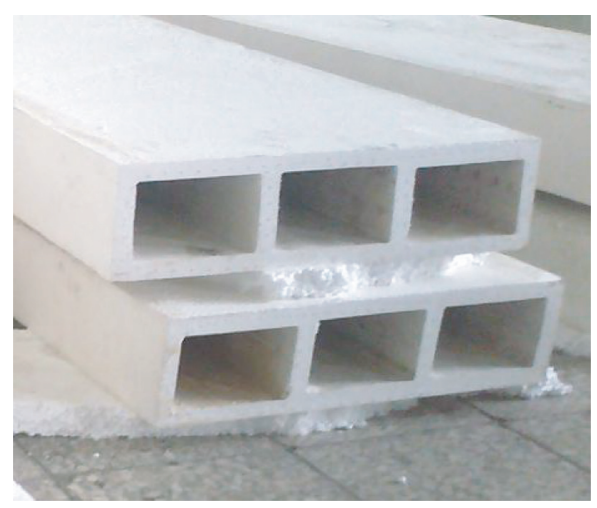

(a)

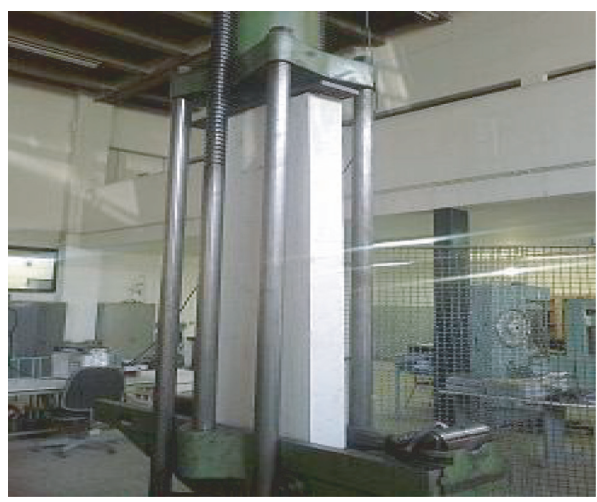

(b)

Figure 1: Gypsum panels used as infill walls [18]. (a) A view of two panels. (b) A specimen under compression test.

TABLE 1: Average mechanical properties of the gypsum [19].

\begin{tabular}{lcccc}
\hline $\begin{array}{l}\text { Tensile } \\
\text { strength } \\
(\mathrm{MPa})\end{array}$ & $\begin{array}{c}\text { Compressive } \\
\text { strength } \\
(\mathrm{MPa})\end{array}$ & $\begin{array}{c}\text { Flexural } \\
\text { strength } \\
(\mathrm{MPa})\end{array}$ & $\begin{array}{c}\text { Shear } \\
\text { strength } \\
(\mathrm{MPa})\end{array}$ & $\begin{array}{c}\text { Young's } \\
\text { modulus } \\
(\mathrm{MPa})\end{array}$ \\
\hline 0.34 & 1.80 & 0.58 & 0.54 & 125 \\
\hline
\end{tabular}

displacement in complete failure, $\delta_{\mathrm{m}}^{\max }=$ maximum effective relative displacement within loading history, and $\alpha=$ damage evolution rate (nondimensional parameter) which is considered 10 in this study. Mortar's damage (tensile and shear) evolution mechanism is schematically shown in Figure 3 [1]:

$$
\left\{\frac{t_{\mathrm{n}}}{t_{\mathrm{n}}^{\mathrm{o}}}\right\}^{2}+\left\{\frac{t_{\mathrm{s}}}{t_{\mathrm{s}}^{\mathrm{o}}}\right\}^{2}+\left\{\frac{t_{\mathrm{t}}}{t_{\mathrm{t}}^{\mathrm{o}}}\right\}^{2}=1
$$

$D=1-\left\{\frac{\delta_{\mathrm{m}}^{\mathrm{o}}}{\delta_{\mathrm{m}}^{\max }}\right\}\left\{1-\frac{1-\exp \left(-\alpha\left(\left(\delta_{\mathrm{m}}^{\max }-\delta_{\mathrm{m}}^{\mathrm{o}}\right) /\left(\delta_{\mathrm{m}}^{\mathrm{f}}-\delta_{\mathrm{m}}^{\mathrm{o}}\right)\right)\right)}{1-\exp (-\alpha)}\right\}$

2.1.3. Masonry. The masonry in the infill wall of the benchmark model follows "concrete damage plasticity" material with the stress-strain behavior proposed by Kent and Park [23] based on the following equation: 


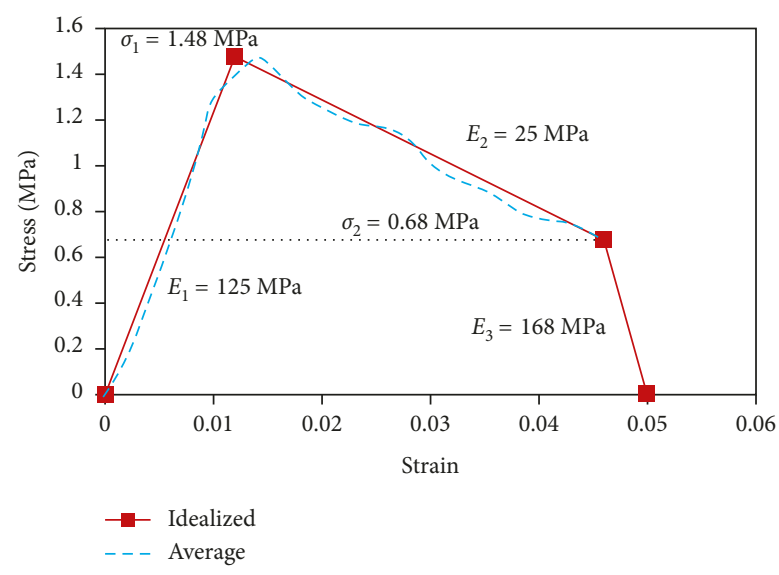

(a)

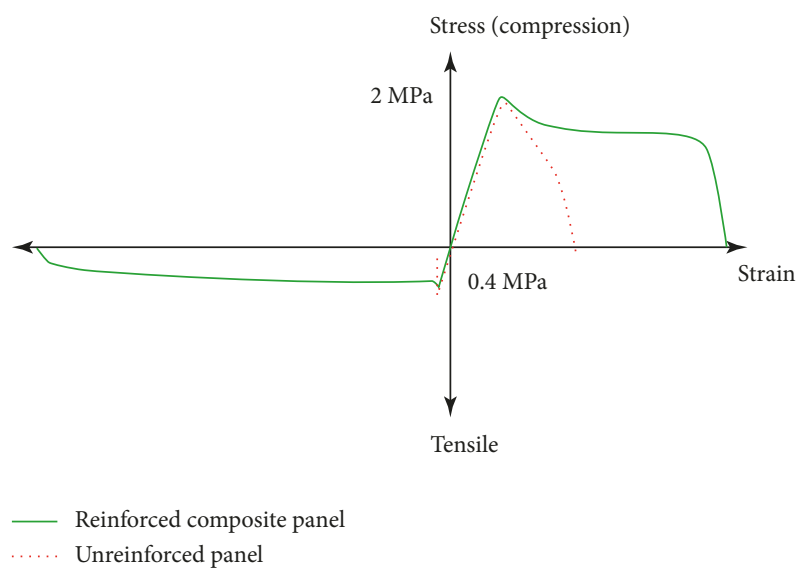

(b)

Figure 2: Stress-strain curve of gypsum. (a) Idealized experimental curve in the compressive regime. (b) Proposed stress-strain model in the compressive regime [19].

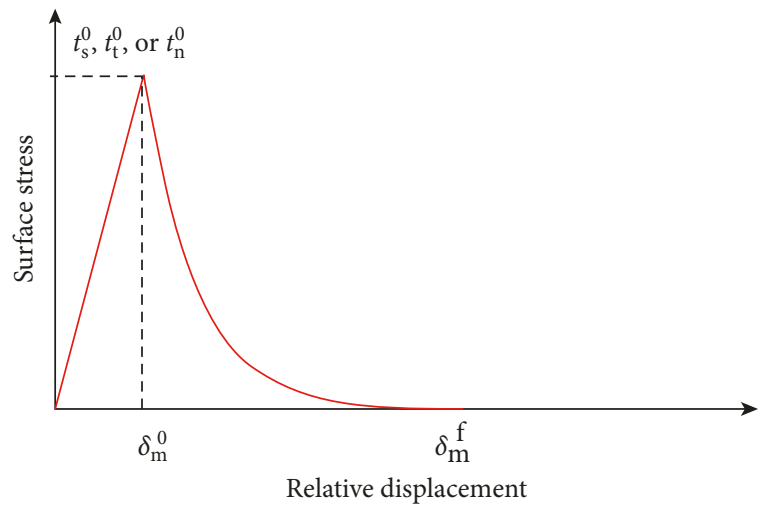

Figure 3: Mortar's damage (tensile and shear) evolution mechanism [1].

$$
\frac{f}{f_{\mathrm{m}}^{\prime}}=\frac{2 \varepsilon}{\varepsilon_{\mathrm{m}}}+\left\{\frac{\varepsilon}{\varepsilon_{\mathrm{m}}}\right\}^{2}=1
$$

where $f_{\mathrm{m}}^{\prime}$ is the compressive strength of masonry, $f$ is the compressive stress, $\varepsilon$ is the compressive strain, and $\varepsilon_{\mathrm{m}}$ is the strain corresponding to the ultimate strength of the material which is based on equation (4). In this equation, $E_{\mathrm{m}}$ is the modulus of elasticity of masonry. The schematic stress-strain behavior of masonry is shown in Figure 4. In this figure, $\sigma$ and $\varepsilon$ represent the stress and strain, respectively; $E_{0}$ denotes the initial modulus of elasticity; and $d_{\mathrm{t}}$ and $d_{\mathrm{c}}$ are tensile and compressive damages, respectively, which control the unloading slope of the stress-strain response. These parameters are assumed to be linearly increasing from zero (undamaged state) to unity (fully damaged state) with respect to plastic strains. $w_{\mathrm{t}}$ and $w_{\mathrm{c}}$ are stiffness recoveries in tensile and compressive states, respectively, which govern the stiffness of stress-strain response during the transition between tensile and compressive zones. It is assumed that $w_{\mathrm{t}}$ and $w_{c}$ are 0.0 and 1.0, respectively, which indicates the

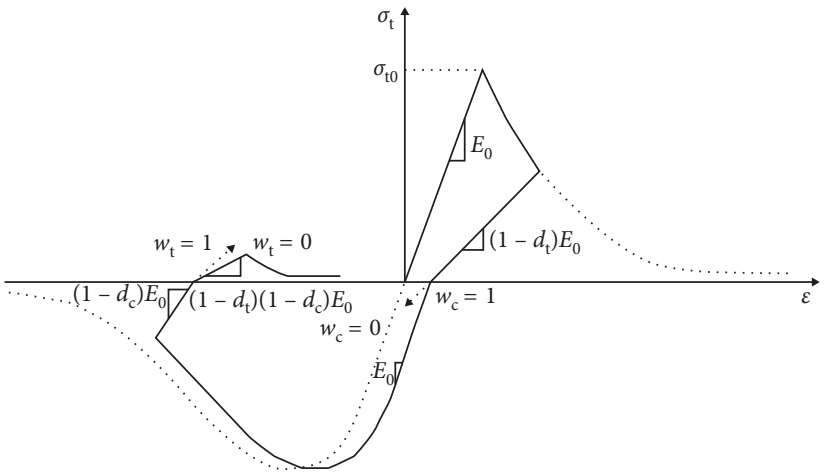

Figure 4: Schematic stress-strain behavior of masonry [1].

material is not affected by tensile damages when goes from the tensile to the compressive regime, while the compressive damages fully influence the tensile behavior upon transition from the compressive to the tensile states [1]:

$$
\varepsilon_{\mathrm{m}}=\frac{f_{\mathrm{m}}^{\prime}}{E_{\mathrm{m}}}
$$

2.1.4. Steel. The stress-strain of steel used in the beam and columns of the frame in the models is assumed to be elasticperfectly plastic with the strain hardening phase. The yielding criterion is von Mises with the yield and the ultimate strength of $260 \mathrm{MPa}$ and $380 \mathrm{MPa}$, respectively.

2.1.5. Verification. In order to ensure the ability of the modeling method and the validity of the assumptions in accurately predicting the response of the infilled frames, Specimen MM after Ghazimahalleh [24] is selected as the benchmark model. The specimen is a steel frame with a masonry infill wall. Mechanical properties of mortar and bricks of the considered specimen are presented in Table 2. 
TABLE 2: Mechanical properties of mortar and bricks in the benchmark specimen.

\begin{tabular}{|c|c|c|c|c|c|c|c|c|}
\hline \multicolumn{5}{|c|}{ Brick } & \multicolumn{4}{|c|}{ Mortar } \\
\hline \multirow[t]{2}{*}{ Linear } & & \multicolumn{3}{|c|}{ Nonlinear } & \multirow{2}{*}{\multicolumn{2}{|c|}{ Tension }} & \multirow{2}{*}{\multicolumn{2}{|c|}{ Shear }} \\
\hline & & Compressive & & Tensile & & & & \\
\hline$E_{\mathrm{m}}\left(\mathrm{N} / \mathrm{mm}^{2}\right)$ & $v$ & $f_{\mathrm{m}}^{\prime}\left(\mathrm{N} / \mathrm{mm}^{2}\right)$ & $f_{\mathrm{t}}\left(\mathrm{N} / \mathrm{mm}^{2}\right)$ & $G_{\mathrm{f}}^{\mathrm{I}}\left(\mathrm{N} \cdot \mathrm{mm} / \mathrm{mm}^{2}\right)$ & $f_{\mathrm{t}}\left(\mathrm{N} / \mathrm{mm}^{2}\right)$ & $G_{\mathrm{f}}^{\mathrm{I}}\left(\mathrm{N} \cdot \mathrm{mm} / \mathrm{mm}^{2}\right)$ & $c\left(\mathrm{~N} / \mathrm{mm}^{2}\right)$ & $\tan \phi \quad G_{\mathrm{f}}^{\mathrm{II}}\left(\mathrm{N} \cdot \mathrm{mm} / \mathrm{mm}^{2}\right)$ \\
\hline 2.7 & 0.15 & 5.95 & 0.40 & 0.23 & 0.25 & 0.01 & 0.39 & $0.65 \quad 0.08$ \\
\hline
\end{tabular}

Note that, for numerical stability, the modulus of elasticity of the cohesive layer is assumed infinite for numerical simplicity and therefore the modulus of elasticity of a masonry prism is assigned to the bricks. Where $E_{\mathrm{m}}$ and $f_{\mathrm{m}}^{\prime}$ are the modulus of elasticity and compressive strength of the masonry prism, respectively.

$v$ is Poisson's ratio of the masonry prism; $f_{\mathrm{t}}$ is the tensile strength of bricks and mortar, and $c$ is the shear strength of mortar; $\tan \phi$ is the friction coefficient between bricks; and $G_{\mathrm{f}}^{\mathrm{I}}$ and $G_{f}^{I I}$ are the tensile and shear softening energy, respectively. The geometrical characteristics of the benchmark model are shown in Figure 5.

Comparison of the failure modes and damages of the numerical model and the experimental specimen is made in Figure 6, and the force-displacement curves of the benchmark model and the corresponding experimental specimen are presented in Figure 7. As can be seen, good correlation between the two sets of results indicate the ability of the numerical modeling in capturing the response parameters of the studied infilled frame models with an acceptable accuracy.

\section{Results and Discussion}

In order to study the effects of gypsum board thickness, the inclusion of fibers as reinforcement in the infill wall, and local strengthening of the peripheral regions of the infill wall, four models are considered for performing a parametric study and their characteristics are presented in Table 3. The selection of each parameter as a variable in these models was made with the aim of evaluation of a distinct effect of each of these parameters on the behavioral characteristics of the studied infilled frames.

The results of the models in terms of the damages in the infill walls are shown in Figure 8. In this figure, the cracks in the peripheral regions of the infill walls from stress concentration between the frame and the infill wall are visible in Model 1 and Model 3. The same pattern of the damages in this region is also observable in the model with the masonry infill wall; albeit with lower intensity due to a larger compressive strength of masonry compared to gypsum and also thicker infill wall. In the masonry infill wall, the damages are more concentrated on the corners of the infill wall in the form of crushing of masonry. A more distinct compressive strut is formed in the model with the masonry infill wall, and as a result, there are some compressive damages at the vicinity of the diagonal of the infill wall. Also, several shear skip cracks are propagated in the masonry infill wall which is originated from weak mortar and strong bricks. None of these damages are observed in the models with gypsum infill walls. It is noted that, in the model with the thick gypsum infill wall (Model 3), a more visible diagonal strut is formed due to higher contribution of the infill in load-bearing mechanical of the infilled frame. Another observation from Figure 8(c) is the reduction of the severity of damages in the peripheral regions of the infill walls, thanks to the strengthening of this region in Model 4.

Another intersecting observation is related to the comparison of the force-displacement curves of the models which are shown in Figure 9. As can be seen, the model with the fibrous gypsum infill wall has the largest strength and ductility. The corresponding model with unreinforced gypsum has similar behavior on lower force levels; however, this models experience significant strength degradation and hence shows much less ductility compared to the corresponding model with fibrous gypsum infill wall. It is noteworthy that the strength and stiffness of the model with the fibrous gypsum infill wall are lower than those of the corresponding model with masonry infill wall. It is because the thickness of the masonry infill is approximately four times of that in the gypsum infill wall; also, the compressive strength of masonry is significantly larger than that of the gypsum material.

3.1. Proposed Strut Model. There are numerous attempts in capturing the general behavior of infilled frames; most of them replacing the infill wall with an equivalent diagonal strut. This approach was first introduced by Holmes which has been improved by many other researchers, e.g., StaffordSmith and Mainstone and Madan et al. According to ASCE 41, the elastic in-plane stiffness of a solid unreinforced masonry infill panel prior to cracking shall be represented with an equivalent diagonal compression strut of width, $a$, given by equation (5). The equivalent strut shall have the same thickness and modulus of elasticity as the infill panel it represents [25-29]:

$$
\alpha=0.254\left(\lambda_{1} h_{\text {col }}\right)^{-0.4} r_{\text {inf }},
$$

where

$$
\lambda_{1}=\left[\frac{10 E_{\mathrm{me}} t_{\mathrm{inf}} \sin 2 \theta}{E_{\mathrm{fe}} I_{\mathrm{col}} h_{\mathrm{inf}}}\right]^{0.25},
$$

$h_{\text {col }}=$ column height between centerlines of beams; $h_{\text {inf }}=$ height of the infill panel; $E_{\mathrm{fe}}=$ expected modulus of elasticity of the frame material; $E_{\mathrm{me}}=$ expected modulus of elasticity of the infill material; $I_{\text {col }}=$ moment of inertia of the column; $L_{\text {inf }}=$ length of the infill panel; $r_{\text {inf }}=$ diagonal length of the infill panel; $t_{\text {inf }}=$ thickness of the infill panel 


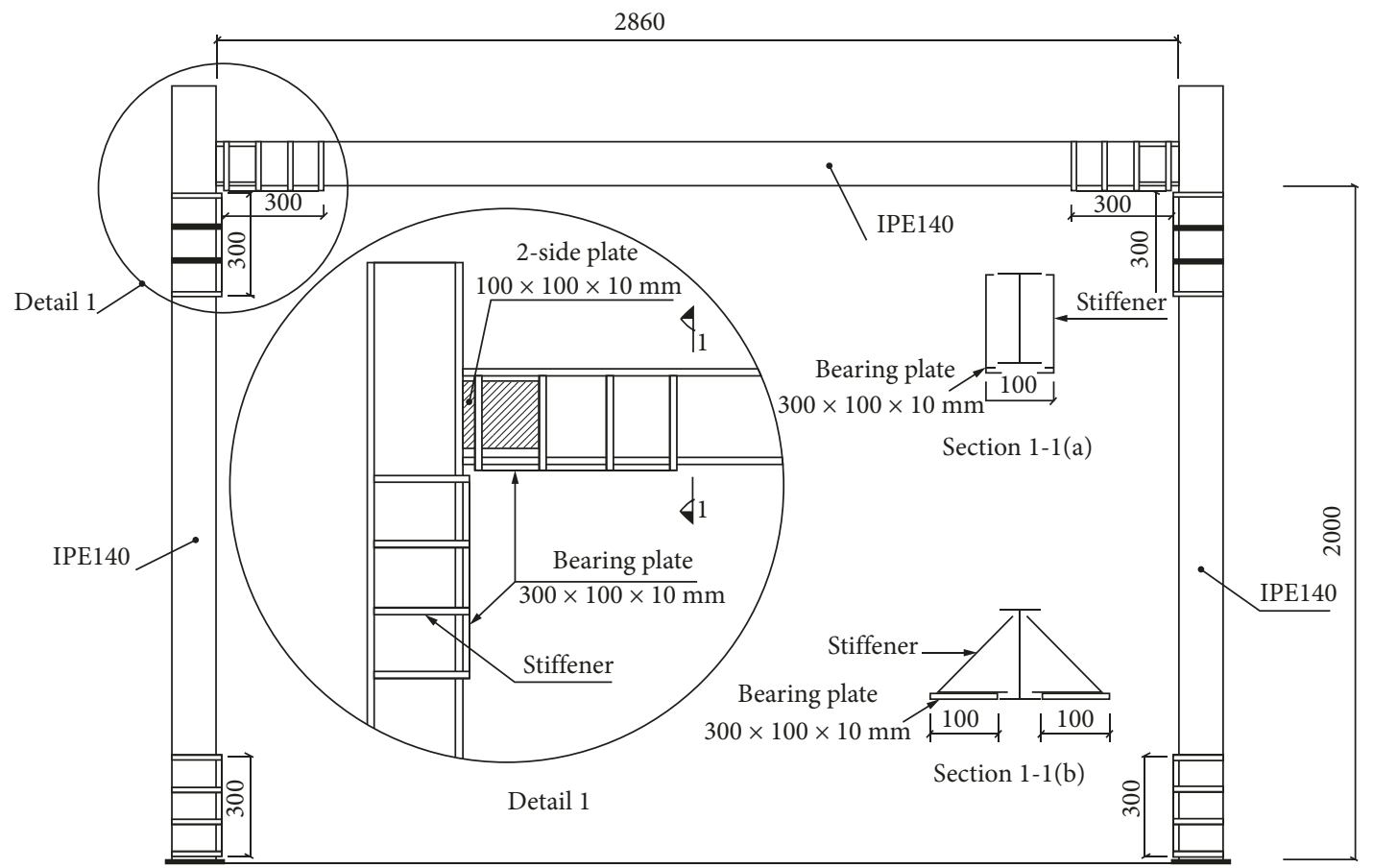

FIgURE 5: Geometrical characteristics of the benchmark model [24].

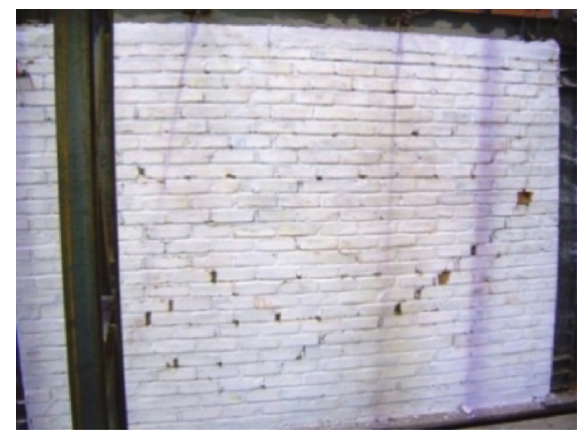

(a)

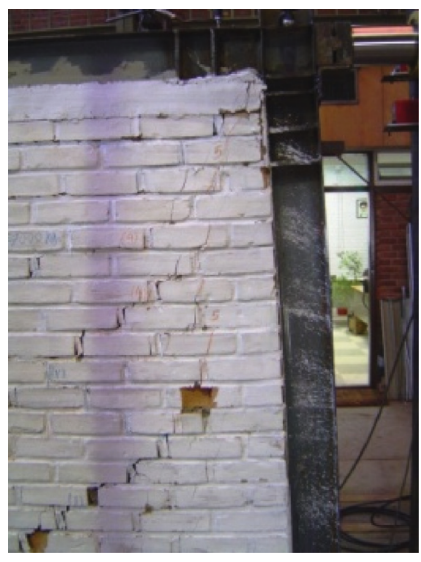

(c)

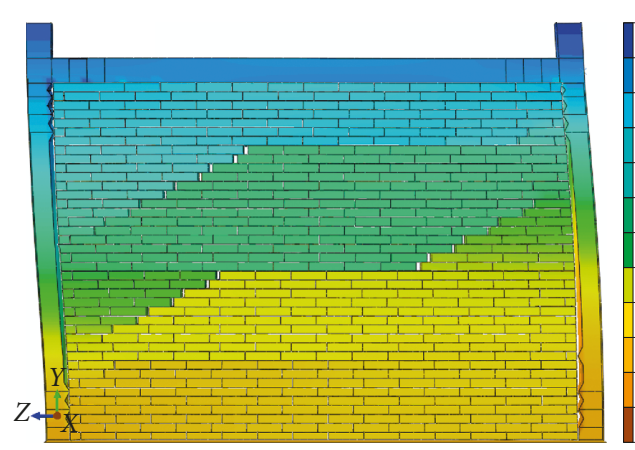

$+1.356 e-02$

$+1.219 e-02$

$+1.082 e-02$

$+9.454 e-03$

$+8.086 e-03$

$+6.718 e-03$

$+5.350 e-03$

$+3.982 e-03$

$+2.614 e-03$

$+1.246 e-03$

$-1.216 e-04$

$-1.490 e-03$

$-2.857 e-03$

(b)

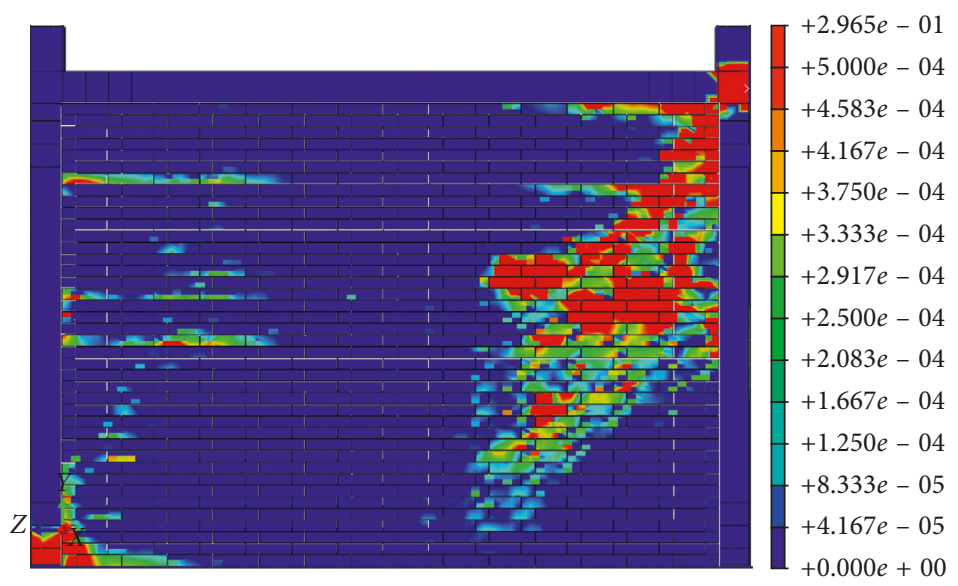

(d)

FIgURE 6: Comparison of the results between the experimental specimen and the numerical model. (a) Failure mode of the experimental specimen [24]. (b) Failure mode of the numerical model. (c) Crushing of bricks in the experimental specimen [24]. (d) Crushing of bricks in the numerical model. 


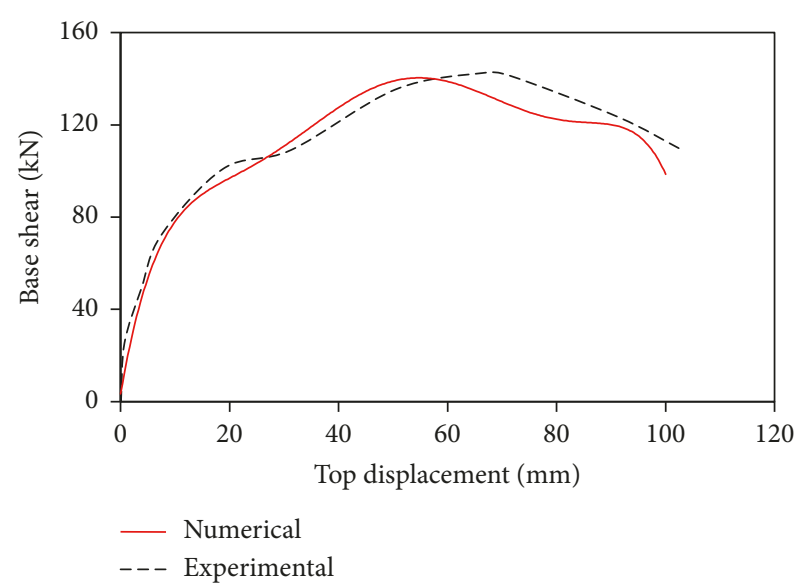

Figure 7: Comparison of the force-displacement curves of the benchmark model and the corresponding experimental specimen.

TABle 3: Characteristics of the models.

\begin{tabular}{lccc}
\hline $\begin{array}{l}\text { Model } \\
\text { name }\end{array}$ & $\begin{array}{c}\text { Infill wall } \\
\text { thickness } \\
(\mathrm{cm})\end{array}$ & Fiber & $\begin{array}{c}\text { Local } \\
\text { strengthening }\end{array}$ \\
\hline M-1 & 3 & $x$ & $\times$ \\
M-2 & 3 & $\checkmark$ & $\times$ \\
M-3 & 9 & $\checkmark$ & $\times$ \\
M-4 & 9 & $\checkmark$ & $\checkmark$ \\
\hline
\end{tabular}

and equivalent strut; $\theta=$ angle whose tangent is the infill height-to-length aspect ratio; and $\lambda_{1}=$ coefficient used to determine equivalent width of the infill strut.

In order to determine the equivalent strut width of the studied models with reinforced gypsum infill walls with the thickness of $6 \mathrm{~cm}$, a set of nine models are considered with various geometrical and mechanical properties of the frame and infill walls. Three profile sizes in the frame members and three lengths of the infill wall are considered in these models which are presented in Table 4 . In order to determine the modified coefficients of the equation (5) for steel frames of reinforced gypsum infill walls, regression analysis is performed on results of the models in Table 3, which leads to the following equation:

$$
\alpha=0.086\left(\lambda_{1} h_{\text {col }}\right)^{-0.4} r_{\text {inf }} .
$$

Formation of the compressive struts is shown in the maximum principal stress contours in the abovementioned models in Figure 10. Force-displacement diagrams of the finite element models are shown in Figure 11. Based on this figure, the stiffness and strength of the models greatly depend on the length of the infill wall and the relative stiffness of the frame to the infill wall.

As expected, the larger frame members lead to higher stiffness and strength of the models. Also, based on Figure 10, the longer the infill walls are related to the wider the equivalent struts which lead to higher stiffness and strength of the infilled frames.

In order to ensure the accuracy of the modified relation for determination of the equivalent strut width of the steel frames with reinforced gypsum infill walls, the frame models in Table 4, with equivalent strut, are analysed. Examples of the deformed shape of the frame models with equivalent strut are shown in Figure 12. The results of the IPE220-series frame models with equivalent strut with those of the finite element models are compared in Figure 13. As can be seen in this figure, the frame models with proposed equivalent strut can acceptably predict the response behavior of the studied infilled frames and hence can be used as a replacement to the finite element modeling. However, these models are usually utilized to simulate the overall response of such infilled frames and hence are unable to capture the more sophisticated response parameters including the internal forces and moments in the frame member and the infill wall as well.

Figure 12 shows the deformed shape of three equivalent strut models with IPE200 at the target displacement. As can be seen, the beams and columns experienced flexural deformations, while the diagonal strut only experiences axial defamations. Also, the inflection points from the lateral loading are observable at the mod length of the beams and columns. Comparison of the force-displacement diagrams of the IPE220-series finite element models with those of the equivalent strut models is presented in Figure 13. As can be seen from this figure, the equivalent strut models acceptably predicted the force-displacement behavior of the models in terms of initial stiffness, ultimate strength, and ductility; however, the difference between the FE model and the equivalent strut model in Model- $4 \mathrm{~m}$ is significant. This can be because of the more shear-dominated behavior of the infill wall in this case as it deviates from the infill wall behavior to the wall because of the considerable length to height ratio.

\section{Conclusions}

In this study, performance of an innovated infill wall made of gypsum panels is investigated using calibrated finite element modeling. Using gypsum as the prefabricated gypsum panels has long been considered in building industry; however, area of applicability of these panels is limited to partition walls, and hence, they are classified as nonstructural components which should tolerate the inertial forces acting on them. As such, these panels are designed with the aim of minimizing the forces acting on them, and hence, they are isolated from the surrounding frames. In this study, these panels are considered as one of the main load-bearing structural components, i.e., infill walls. Because of significant induced forces in infill walls and low strength and ductility of gypsum, fibers were added during construction of these panels to increase their contribution in load-bearing mechanism which is contrary to the present approach which aims at isolating these panels from other structural components.

By performing calibrated numerical simulation on four infilled frame models, taking into account the effects of gypsum board thickness, the inclusion of fibers as reinforcement in the infill wall, and local strengthening of the peripheral regions of the infill wall, the observations are made which are as follows: 
PE, max, principal

SNEG (fraction $=-1.0$ )

(avg: 75\%)

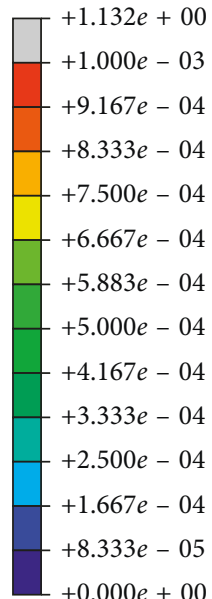

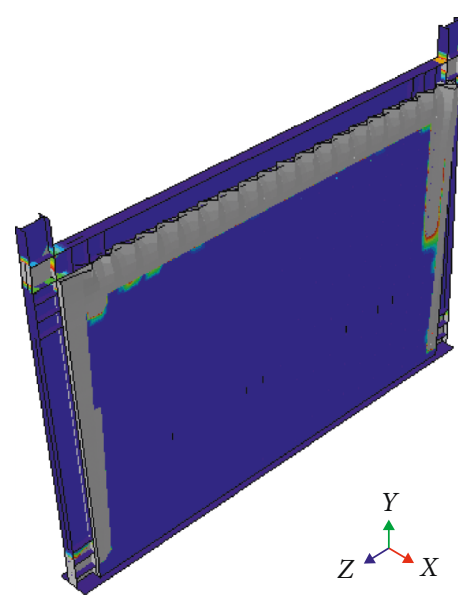

(a)
PE, max, in-plane principal SNEG (fraction $=-1.0$ ) (avg: 75\%)
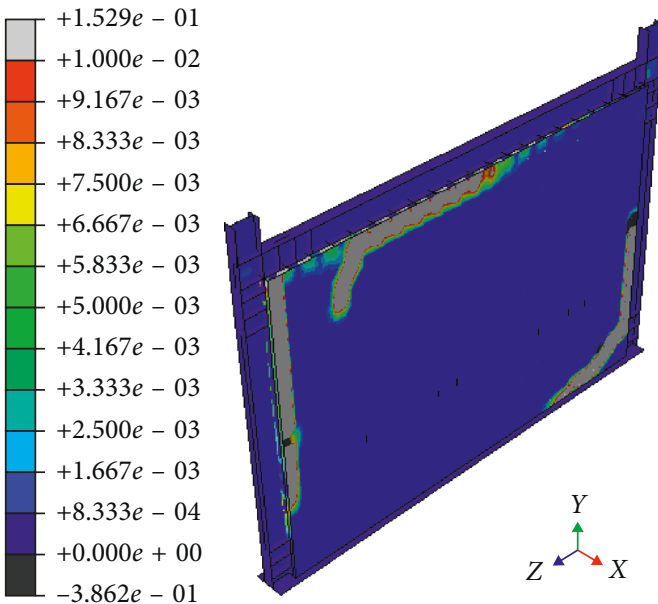

(b)

PE, max, in-plane principal SNEG $($ fraction $=-1.0)$ (avg: $75 \%$ )
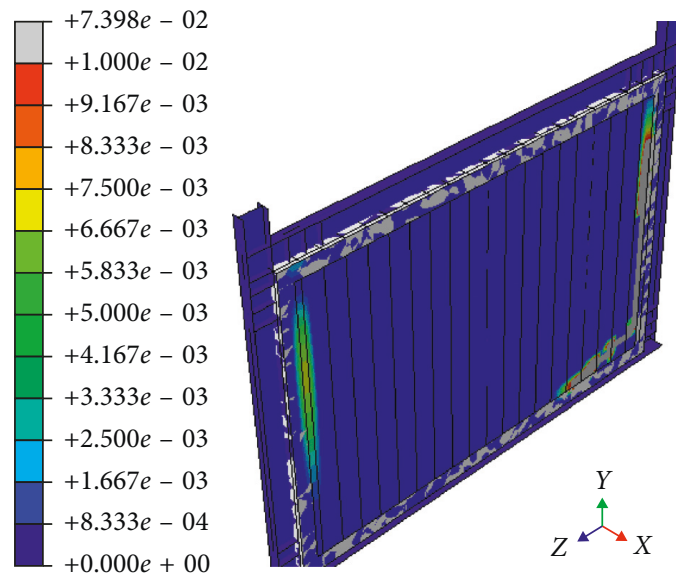

(c)

Figure 8: Results of the models in terms of damages in the infill walls. (a) M-1. (b) M-3. (c) M-4.

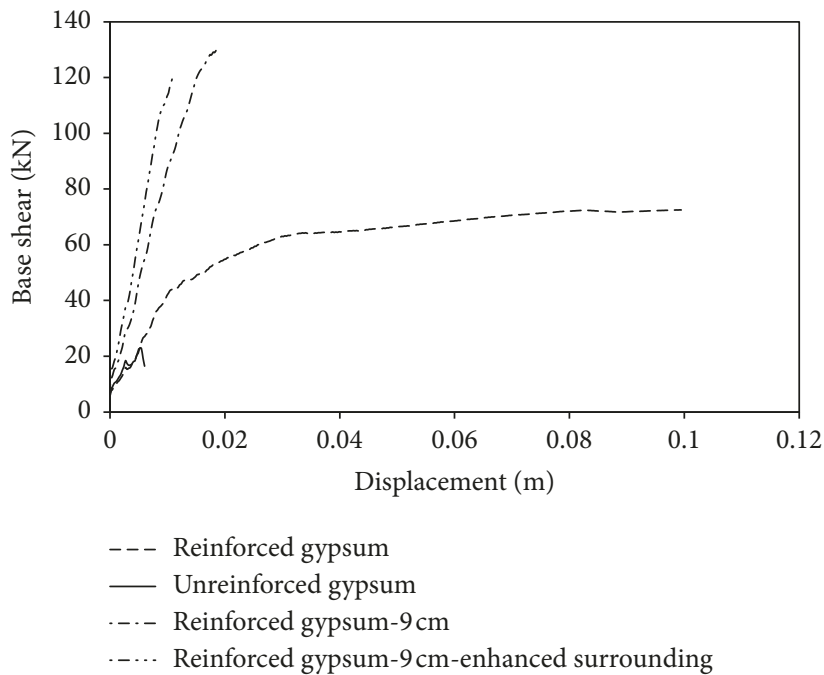

FIgURE 9: Comparison of the force-displacement curves of the models. 
TABLE 4: Characteristics of the models with reinforced gypsum for determination of the equivalent strut width.

\begin{tabular}{lcccc}
\hline Model name & Length $(\mathrm{cm})$ & Frame profile & $\begin{array}{c}\text { Equivalent strut width (cm) } \\
\text { based on ASCE 41 [27] }\end{array}$ & $\begin{array}{c}\text { Proposed equivalent } \\
\text { strut width }(\mathrm{cm})\end{array}$ \\
\hline M-1.8m-IPE140 & 1.8 & IPE140 & 36 & 12 \\
M-2.9m-IPE140 & 2.9 & IPE140 & 48 & 16 \\
M-4.0m-IPE140 & 4.0 & IPE140 & 62 & 21 \\
M-1.8m-IPE180 & 1.8 & IPE180 & 40 & 13 \\
M-2.9m-IPE180 & 2.9 & IPE180 & 52 & 17 \\
M-4.0m-IPE180 & 4.0 & IPE180 & 68 & 23 \\
M-1.8m-IPE220 & 1.8 & IPE220 & 43 & 14 \\
M-2.9m-IPE220 & 2.9 & IPE220 & 56 & 19 \\
M-4.0m-IPE220 & 4.0 & IPE220 & 73 & 25 \\
\hline
\end{tabular}

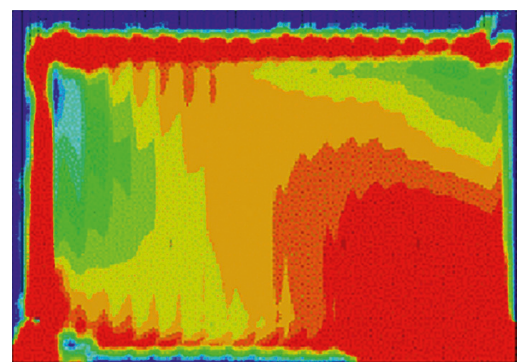

(a)

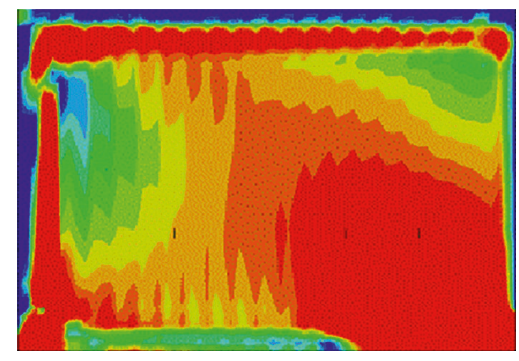

(d)

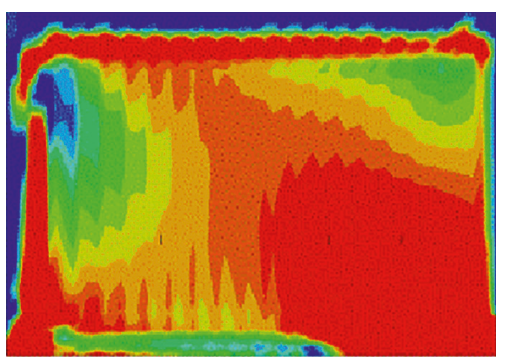

(g)

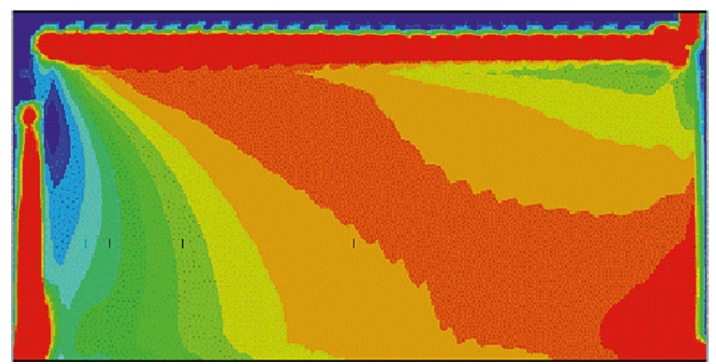

(b)

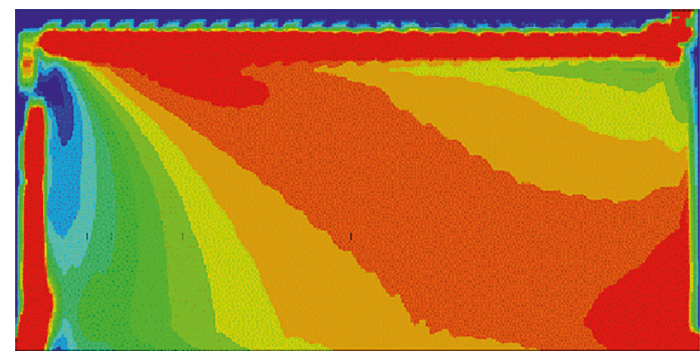

(e)

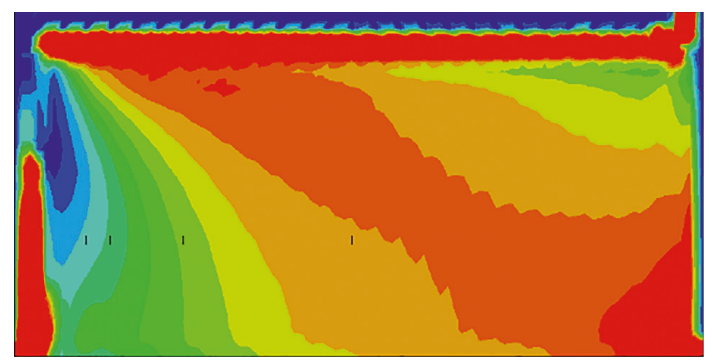

(h)

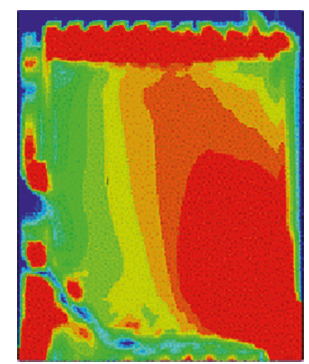

(c)

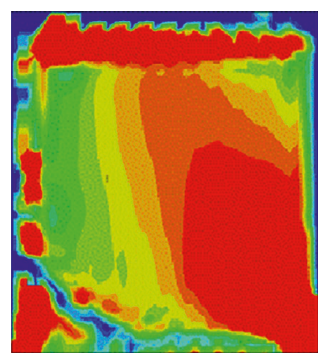

(f)

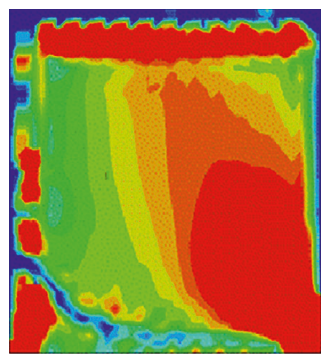

(i)

Figure 10: Formation of the compressive struts. (a) M-1.8m-IPE140. (b) M-2.9m-IPE140. (c) M-4.0m-IPE140. (d) M-1.8m-IPE180. (e) M2.9m-IPE180. (f) M-4.0m-IPE180. (g) M-1.8m-IPE220. (h) M-2.9m-IPE220. (i) M-4.0m-IPE220.

(1) The inclusion of fiber to the infill wall leads to an increase in the strength and ductility of the models up to 3.2 and 6.3 times, respectively.

(2) Doubling the thickness of the infill leads to an increase of 6.7 and 3.3 times in strength and stiffness, respectively; however, this modification causes a significant decrease in the ductility of the infilled frame. This reduction in ductility can be attributed to the fact that, by increasing the thickness of the infill walls, its contribution in the load-bearing mechanism increases. Because the stress-strain behavior of gypsum has a significantly lower ductility than that of the steel materials, the models with stronger infill walls show lower ductility in response.

(3) Negligible improvement in strength and ductility is achieved through local strengthening of the peripheral regions of the infill wall, whereas it leads to a $30 \%$ increase in the stiffness of the models. The strengthening of the infill wall was based on the observed damages of the previous models in which the 


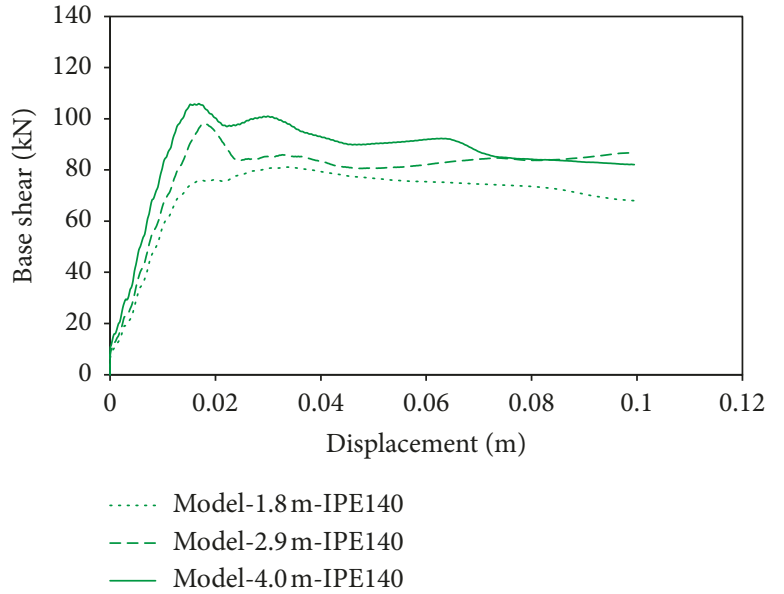

(a)

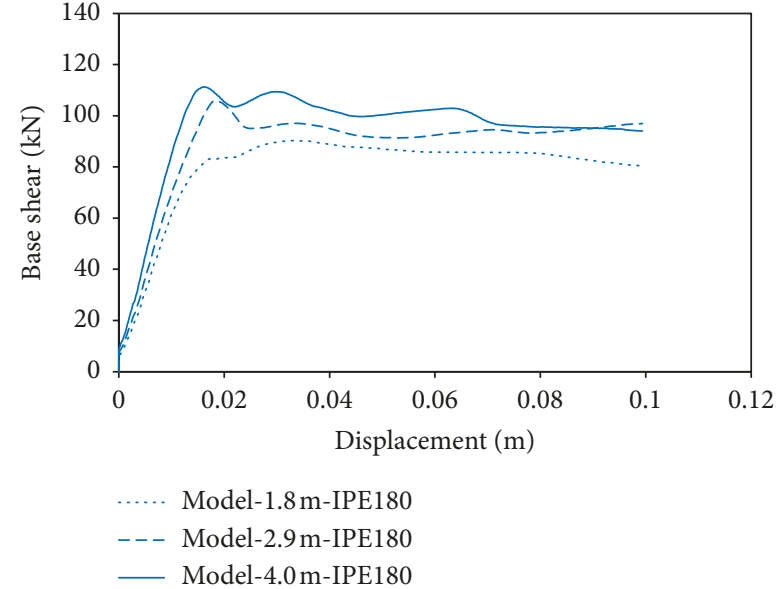

(b)

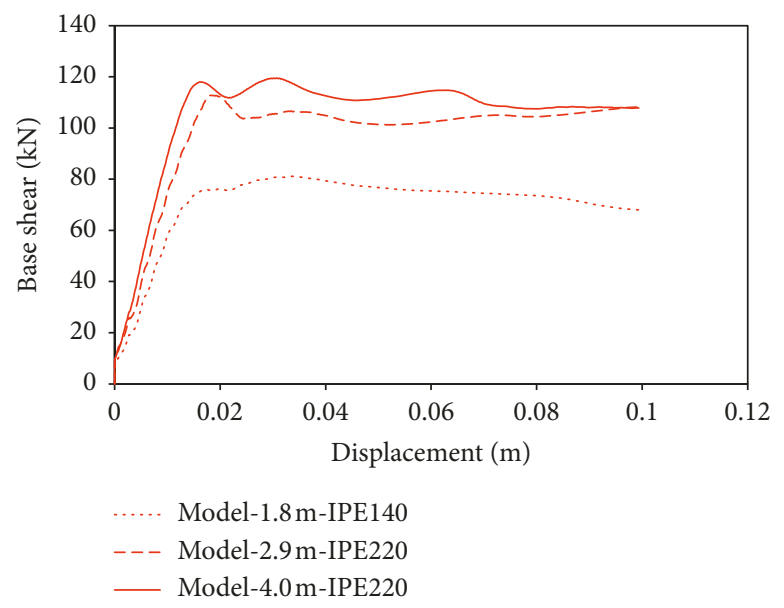

(c)

FIGURE 11: Force-displacement diagrams of the finite element models with (a) IPE140, (b) IPE180, and (c) IPE220.

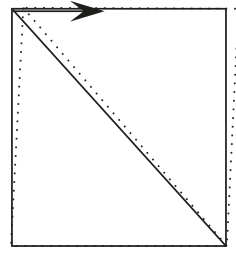

(a)

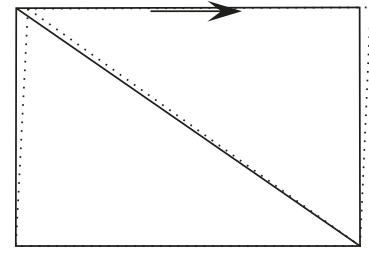

(b)

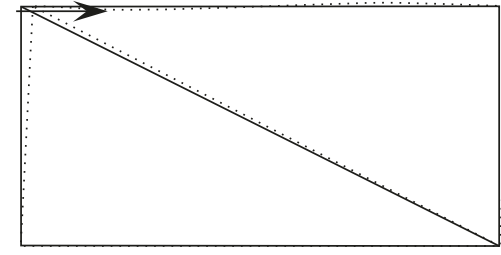

(c)

Figure 12: Deformed shape of the equivalent strut models with IPE220. (a) M-1.8m-IPE220. (b) M-2.9m-IPE220. (c) M-4.0m-IPE220.

peripheral regions of the infill walls experience severe cracking because of stress concentration. By the way, this modification had negligible effects on the performance improvement of the studied infill frames.

It is noteworthy that, in many cases, infill walls have opening in the form of door and/or window. Presence of openings has considerable influence on the response characteristics of the infilled frames including reduction in stiffness and strength and also changes in ductility and energy dissipation capacity [30-32]. The corners of the openings are among the most vulnerable locations in the infill walls, and care must be taken in providing the local added reinforcement in this area. Efforts should be made in order to investigate the performance of perforated gypsum infill walls which falls within the subject of several papers. Also, performance of the proposed reinforced gypsum infill walls under out-of-plane forces should be studied as in some cases; these panels show vulnerability against design-level earthquake forces in this direction. Though unlike the in-plane response, there are still challenges in simplification of the out-of-plane response of the infilled frames using equivalent strut models. Hence, the utilized modeling method in this study, i.e., simplified 


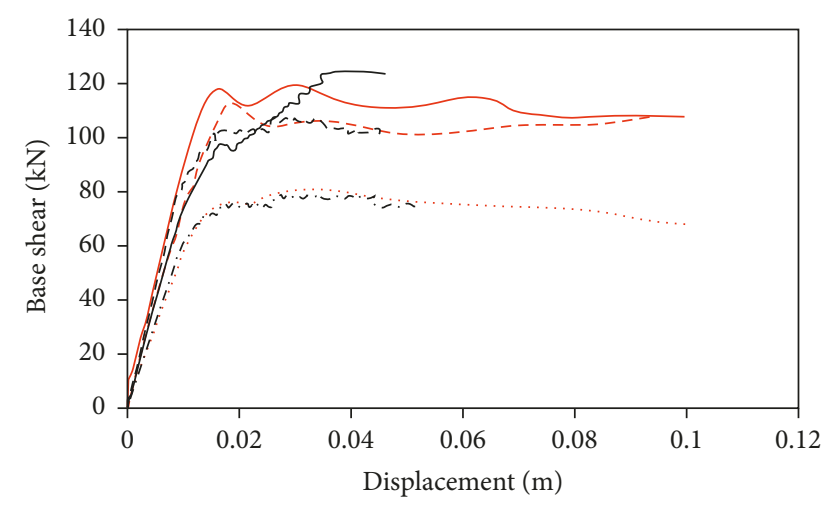

$$
\begin{aligned}
& \text {..... Model-1.8 m-IPE140 } \\
& \text { - - - Model-2.9 m-IPE220 } \\
& \text { — Model-4.0m-IPE220 } \\
& \text {-. - Model-1.8 m-IPE220-equivalent strut } \\
& \text { — Model-4.0 m-IPE220-equivalent strut } \\
& \text { - - - Model-2.9 m-IPE220-equivalent strut }
\end{aligned}
$$

FIgURE 13: Comparison of the force-displacement diagrams of the IPE220-series finite element models with those of the equivalent strut models.

micromodeling, can also be used in studying the behavior of gypsum infill walls under out-of-plane seismic demands [33].

\section{Data Availability}

The experimental data used to support the findings of this study have been included in the following paper by the first author of the current paper which has been cited: M. Tabeshpoor and M. Movahednia, "Using Reinforced Composite Panel as Barrier Wall," in The Third National Conference of Construction Innovative Technologies, 2017, pp. 1-9. The numerical model data (including the input files of Abaqus) used in this study are available from the corresponding author upon request.

\section{Conflicts of Interest}

The authors declare that they have no conflicts of interest.

\section{References}

[1] V. Bahreini, T. Mahdi, and M. M. Najafizadeh, "Evaluation of brick infill walls under in-plane and out-of-plane loading," Journal of Vibroengineering, vol. 19, no. 1, pp. 394-408, 2017.

[2] P. G. Asteris, A. K. Tsaris, L. Cavaleri et al., "Prediction of the fundamental period of infilled RC frame structures using artificial neural networks," Computational Intelligence and Neuroscience, vol. 2016, Article ID 5104907, 12 pages, 2016.

[3] P. G. Asteris, "The FP4026 Research Database on the fundamental period of RC infilled frame structures," Data in Brief, vol. 9, pp. 704-709, 2016.

[4] P. G. Asteris, C. C. Repapis, F. Foskolos, A. Fotos, and A. K. Tsaris, "Fundamental period of infilled RC frame structures with vertical irregularity," Structural Engineering and Mechanics, vol. 61, no. 5, pp. 663-674, 2017.

[5] P. G. Asteris, C. C. Repapis, E. V. Repapi, and L. Cavaleri, "Fundamental period of infilled reinforced concrete frame structures," Structure and Infrastructure Engineering, vol. 13, no. 7, pp. 929-941, 2016.

[6] P. Zak, T. Ashour, A. Korjenic, S. Korjenic, and W. Wu, “The influence of natural reinforcement fibers, gypsum and cement on compressive strength of earth bricks materials," Construction and Building Materials, vol. 106, pp. 179-188, 2016.

[7] M. A. Ali and F. J. Grimer, "Mechanical properties of glass fibre-reinforced gypsum," Journal of Materials Science, vol. 4, no. 5, pp. 389-395, 1969.

[8] Y.-F. Wu and M. P. Dare, "Flexural and shear strength of composite lintels in glass-fiber-reinforced gypsum wall constructions," Journal of Materials in Civil Engineering, vol. 18, no. 3, pp. 415-423, 2006.

[9] M. Janardhana, P. Robin Davis, S. S. Ravichandran, A. M. Prasad, and D. Menon, "Calibration of a hysteretic model for glass fiber reinforced gypsum wall panels," Earthquake Engineering and Engineering Vibration, vol. 13, no. 2, pp. 347-355, 2014.

[10] V. Macillo, B. Bucciero, M. T. Terracciano, T. Pali, L. Fiorino, and R. Landolfo, "Shaking table tests on cold-formed steel building sheathed with gypsum panels," Seismic Resistance, vol. 1, no. 2-3, 2017.

[11] S. Selvaraj and M. Madhavan, "Behaviour of gypsum sheathed cold-formed steel stud walls under lateral loadings," ColdFormed Structures, vol. 1, no. 2-3, 2017.

[12] S. Amer, S. Hamoush, and T. Abu-Lebdeh, "In-plane performance of gypsum board partition wall systems subjected to cyclic loadings," Journal of Constructional Steel Research, vol. 124, pp. 23-36, 2016.

[13] V. Macillo, L. Fiorino, and R. Landolfo, "Seismic response of CFS shear walls sheathed with nailed gypsum panels: experimental tests," Thin-Walled Structures, vol. 120, pp. 161171, 2017.

[14] Y.-F. Wu, "The structural behavior and design methodology for a new building system consisting of glass fiber reinforced gypsum panels," Construction and Building Materials, vol. 23, no. 8, pp. 2905-2913, 2009.

[15] V. M. Mujeeb and R. Udhayasakthi, "Case study on glass fiber reinforced gypsum panel in mass house economics," The Asian Review of Civil Engineering, vol. 6, no. 2, pp. 15-19, 2017.

[16] S. Paul, P. Cherian, D. Menon, and A. M. Prasad, "Use of glass fibre reinforced gypsum panels with reinforced concrete infills for construction of walls and slabs," Indian Concrete Journal, vol. 90, no. 12, pp. 19-32, 2017.

[17] P. Cherian, S. Paul, S. R. G. Krishna, D. Menon, and A. Meher Prasad, "Mass housing using GFRG panels: a sustainable, rapid and affordable solution," Journal of The Institution of Engineers (India): Series A, vol. 98, no. 1-2, pp. 95-100, 2017.

[18] M. Tabeshpoor and M. Movahednia, "Using reinforced composite panel as barrier wall," in Proceedings of Third National Conference of Construction Innovative Technologies, pp. 1-9, Cádiz, Spain, October 2017.

[19] Research and Development Department of Banaye Rasis, New Technology in Construction Industry (Easywall), Fadak Issatis publication, Tehran, Iran, 2012.

[20] A. Khennane, Introduction to Finite Element Analysis Using MATLAB ${ }^{\circledR}$ and Abaqus, CRC Press, Boca Raton, FL, USA, 2013.

[21] S. Helwany and H. Sam, Applied Soil Mechanics with ABAQUS Applications, John Wiley \& Sons, Hoboken, NJ, USA, 2007.

[22] K. A. S. Hibbit, Abaqus Theory and User Manuals Version 6.9, USA ABAQUS Inc, Pawtucket, RI, USA, 2009. 
[23] D. C. Kent and R. Park, "Flexural members with confined concrete," Journal of the Structural, vol. 97, no. 7, pp. 19691990, 1971.

[24] M. M. Ghazimahalleh, "Stiffness and damping of infilled steel frames," Proceedings of the Institution of Civil EngineersStructures and Buildings, vol. 160, no. 2, pp. 105-118, 2007.

[25] M. Holmes, "Steel frames with brickwork and concrete infilling," Proceedings of the Institution of Civil Engineers, vol. 19, no. 4, pp. 473-478, 1961.

[26] B. S. Smith, "Methods for predicting the lateral stiffness and strength of multi-storey infilled frames," Building Science, vol. 2, no. 3, pp. 247-257, 1967.

[27] R. J. Mainstone, "On the stiffness and strength of in-filled frames," Proceedings of the Institution of Civil Engineers New York, vol. 49, no. 2, 1974.

[28] (ASCE/SEI 41-06), Seismic Rehabilitation of Existing Buildings (ASCE/SEI 41-06), American Society of Civil Engineers, Reston, VA, USA, 2007.

[29] A. Madan, A. M. Reinhorn, J. B. Mander, and R. E. Valles, "Modeling of masonry infill panels for structural analysis," Journal of Structural Engineering, vol. 123, no. 10, pp. 12951302, 1997.

[30] P. G. Asteris, D. M. Cotsovos, C. Z. Chrysostomou, A. Mohebkhah, and G. K. Al-Chaar, "Mathematical micromodeling of infilled frames: state of the art, engineering structures, engineering structures," Engineering Structures, vol. 56, pp. 1905-1921, 2013.

[31] P. G. Asteris, S. T. Antoniou, D. S. Sophianopoulos, and C. Z. Chrysostomou, "Mathematical macromodelling of infilled frames: state of the art," Journal of Structural Engineering, vol. 137, no. 12, pp. 1508-1517, 2011.

[32] P. G. Asteris, C. Z. Chrysostomou, I. P. Giannopoulos, and E. Smyrou, "Masonry infilled reinforced concrete frames with openings, COMPDYN 2011," in Proceedings of III ECCOMAS Thematic Conference on Computational Methods in Structural Dynamics and Earthquake Engineering, pp. 26-28, Corfu, Greece, May 2011.

[33] P. G. Asteris, L. Cavaleri, F. Di Trapani, and A. K. Tsaris, "Numerical modelling of out-of-plane response of infilled frames: state of the art and future challenges for the equivalent strut macromodels," Engineering Structures, vol. 132, pp. 110-122, 2017. 


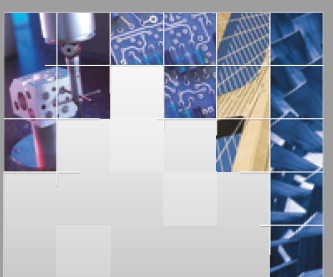

\section{Enfincering}
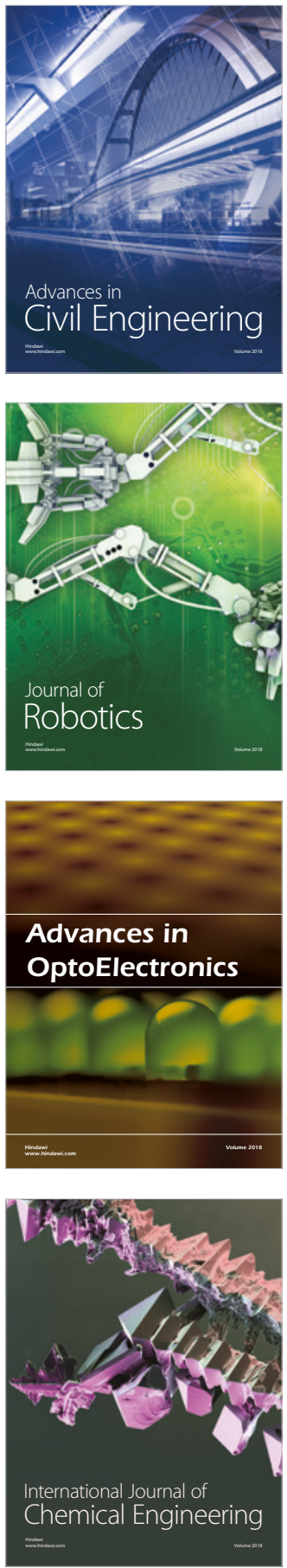

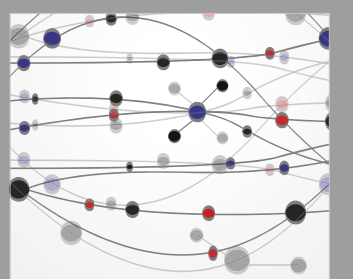

\section{Rotating \\ Machinery}

The Scientific World Journal

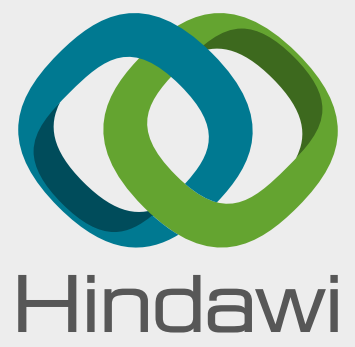

Submit your manuscripts at

www.hindawi.com
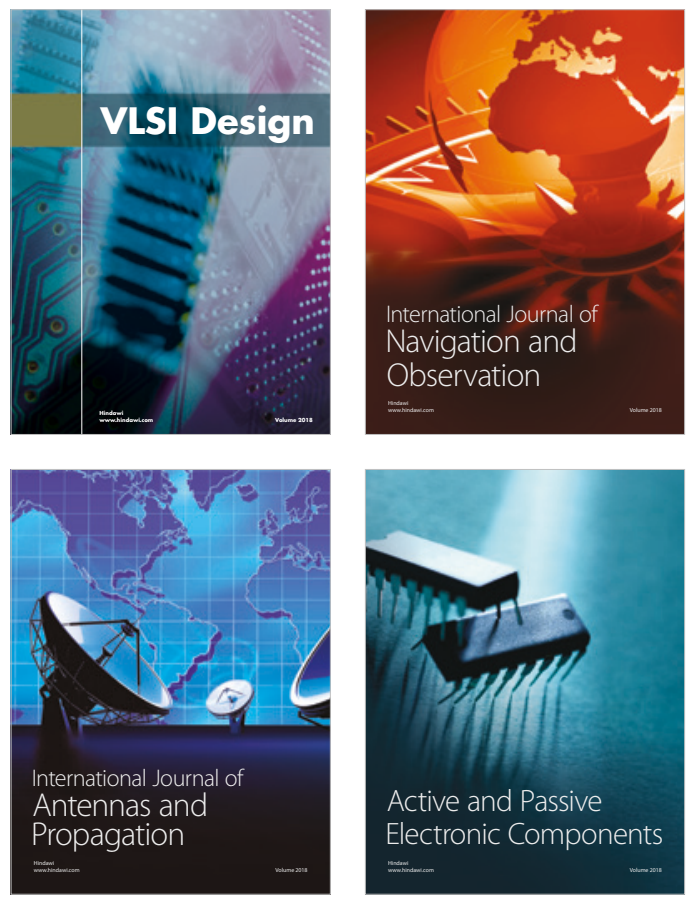
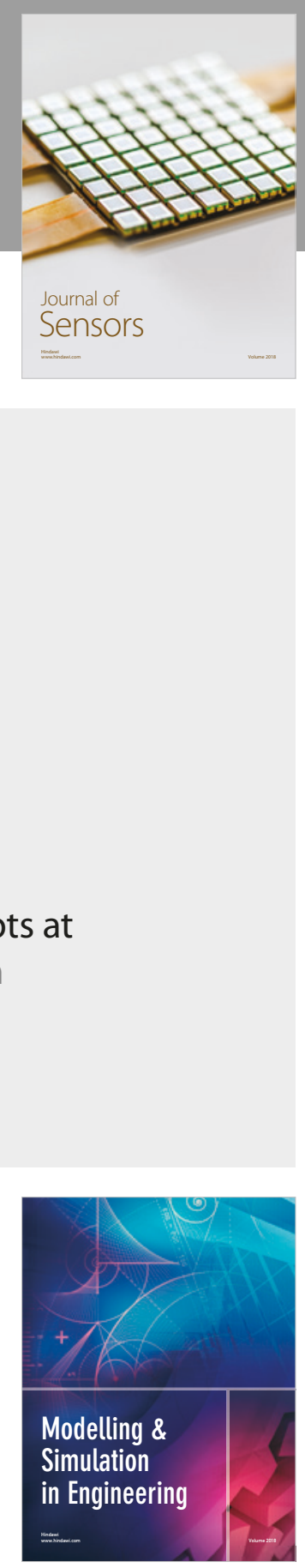

\section{Advances \\ Multimedia}
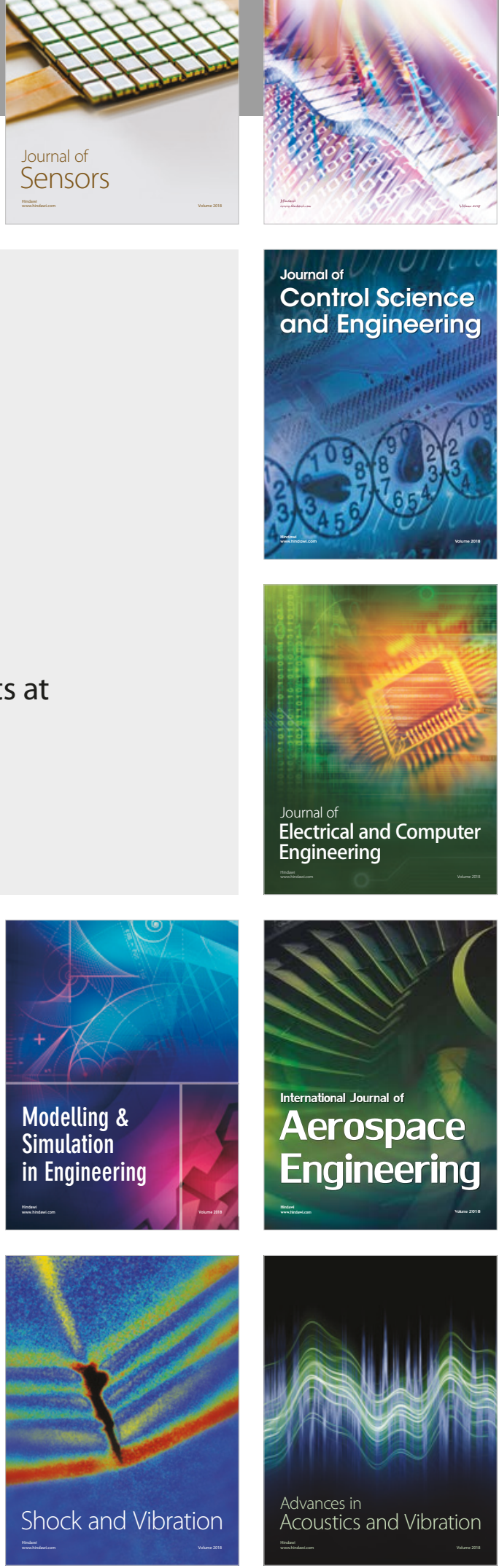